\title{
Developing a cure for Black Bone Disease
}

\author{
Nicolas T Sireau \\ From 6th European Conference on Rare Diseases and Orphan Products \\ Brussels, Belgium. 23-25 May 2012
}

Alkaptonuria (AKU for short) was the first genetic disease ever identified as such, by Dr Archibald Garrod in 1901 in London [1]. It is a rare disease affecting approximately one in 250,000 people, apart from countries such as Slovakia, Jordan and parts of South India where the number is up to 10 times higher [2]. Alkaptonuria is a monogenic disease leading to an enzyme deficiency, causing the accumulation of homogentisic acid (HGA) at 2,000 times the normal rate [3]. The HGA binds to cartilage and bone and pigments, turning it black in a process called ochronosis hence its name of Black Bone Disease. The AKU Society, a patient advocacy group, has worked in close partnership with the Royal Liverpool University Hospital and the University of Liverpool over the past nine years to develop a major programme of research and treatment. This started with the post-mortem of an AKU patient [4], funded through sponsored events, followed by the funding of a $\mathrm{PhD}$ programme that developed an in vitro model of AKU [5]. Thanks to support from the Big Lottery Fund, the AKU Society then funded a four-year programme at UoL that successfully created an animal model of AKU, in which new therapies are being tested. The AKU Society and RLUH in parallel launched a global campaign to identify AKU patients [6], starting with three patients in the UK and reaching more than 1,000 patients globally by 2012. AKU patients and their families set up formal AKU Societies in the UK, France, Germany, the Netherlands, Italy, the USA and Canada in order to build the patient movement. A study was carried out to find out the average cost of an AKU patient to the National Health Service: $£ 100,000$ a year. This was used to build a case to the NHS for funding the National Alkaptonuria Society at RLUH and launching it in June 2012. The AKU Society, RLUH and UoL led the creation of an international consortium including 15 pharma companies, biotechs, universities, clinical trial centres, patient groups and contract research organisations in eight countries across Europe and North

Correspondence: nick@akusociety.org

Alkaptonuria Society, Cambridge, CB2 9JG, UK
America. Thanks to funding from the European Commission, this consortium will launch in late 2012 a five-and-ahalf year clinical development programme to develop and obtain marketing authorisation for nitisinone, a small molecule that inhibits the accumulation of homogentisic acid. Further AKU research centres have also been established in Jordan and South India.

Published: 22 November 2012

\section{References}

1. Garrod E: The Croonian lectures on inborn errors of metabolism. Lecture II. Alkaptonuria. Lancet 1908, 2:73-9.

2. Zatkova $\mathrm{A}$, de Bernake $\mathrm{DB}$, Polakova $\mathrm{H}$, et al: High frequency of alkaptonuria in Slovakia: evidence for the apparence of multiple mutations in HGO involving different mutational hot spots. Am J Hum Genet 2001, 68(5):1313.

3. Phomphutkul C, Introne WJ, Perry MB, et al: Natural History of Alkaptonuria. N Engl J Med 2002, 347(26):2111-21.

4. Helliwell TR, Gallagher JA, Ranaganth L: Alkaptonuria - a review of surgical and autopsy pathology. Histopathology 2008, 53(5):503-12.

5. Tinti L, Taylor AM, Santucci A, et al: Development of an in vitro model to investigate joint ochronosis in Alkaptonuria. Rheumatology (Oxford) 2011, 50(2):271-7.

6. Ranganath LR, Taylor AM, Gallagher JA, et al: Identification of AKU in the General Population: A United Kingdom experience describing the challenges, possible solutions and persistant barrier. J Inherit Metab Dis 2011, 34:723-730.

doi:10.1186/1750-1172-7-S2-A37

Cite this article as: Sireau: Developing a cure for Black Bone Disease. Orphanet Journal of Rare Diseases 2012 7(Suppl 2):A37.

\section{Submit your next manuscript to BioMed Central} and take full advantage of:

- Convenient online submission

- Thorough peer review

- No space constraints or color figure charges

- Immediate publication on acceptance

- Inclusion in PubMed, CAS, Scopus and Google Scholar

- Research which is freely available for redistribution

\section{Ciomed Central}

C 2012 Sireau; licensee BioMed Central Ltd. This is an Open Access article distributed under the terms of the Creative Commons Attribution License (http://creativecommons.org/licenses/by/2.0), which permits unrestricted use, distribution, and reproduction in any medium, provided the original work is properly cited. 